\title{
Board of Directors and General Manager Role in Organization Governance and Attention to Board of Directors' Characteristics Components
}

\author{
Ali Taghavi Moghaddam ${ }^{1}$, Abolghassem Massihabadee ${ }^{2 *}$, Mohamadreza Shorvarzi ${ }^{1}$, \\ Alireza Mehrazeen ${ }^{1}$ \\ ${ }^{1}$ Department of Accounting, Neyshabur Branch, Islamic Azad University, Neyshabur, Iran \\ ${ }^{2}$ Department of Accounting, Sabzevar Branch, Islamic Azad University, Sabzevar, Iran
}

\begin{tabular}{|c|c|}
\hline & ABSTRACT \\
\hline \multicolumn{2}{|l|}{ Keywords: } \\
\hline $\begin{array}{l}\text { Board of Directors } \\
\text { Characteristics, } \\
\text { Organization Governance, } \\
\text { Organization Function }\end{array}$ & $\begin{array}{l}\text { Board of directors and General Manager are considered the most important factors in } \\
\text { control and supervision on firm management and shareholders' resources protection. The } \\
\text { board of directors' main responsibility is to set up efficient governance on the firm affairs in } \\
\text { alignment with shareholders' interests and balance in the interests of its different }\end{array}$ \\
\hline $\begin{array}{l}\text { Received } \\
17 \text { November } 2017\end{array}$ & $\begin{array}{l}\text { beneficiarles including customers, statt, investors and local societies, to provide } \\
\text { independent supervision on executive directors' function, and to challenge the commercial } \\
\text { decisions and strategy of executive management Board of directors is the ultimate }\end{array}$ \\
\hline $\begin{array}{l}\text { Received in revised form } \\
14 \text { June } 2018\end{array}$ & $\begin{array}{l}\text { responsible for operations and financial health of the firm as well. Studies about board of } \\
\text { directors' characteristics can be divided into two domains of components associated with }\end{array}$ \\
\hline $\begin{array}{l}\text { Accepted } \\
20 \text { June } 2018\end{array}$ & $\begin{array}{l}\text { board of directors' characteristics and its effect on other variables. The current gap in } \\
\text { literature creates motivations for this study. No comprehensive study has been initially }\end{array}$ \\
\hline & $\begin{array}{l}\text { existed so far in terms of the board of directors' characteristics measurement. Issues } \\
\text { associated with measurement in social sciences and board of directors' characteristics scales } \\
\text { have been rarely discussed in accounting literature. However, this study fills these gaps in }\end{array}$ \\
\hline $\begin{array}{l}\text { Correspondence: } \\
\text { massihabadi@gmail.com }\end{array}$ & $\begin{array}{l}\text { literature and prepares a wide review of board of directors' characteristics scales existing in } \\
\text { accounting literature. Furthermore, this review discusses the existing measurement issues in } \\
\text { the board of directors' characteristics concept and prepares recommendations for } \\
\text { considering the current issues in the future research. }\end{array}$ \\
\hline
\end{tabular}

(C)AIMI Journals

Board of directors is the highest decision making authority in organizations. A great deal of decisions made by them are effective on their wealth. They control the selection and deposition of the highest executive positions and supervise their execution, and approve many of 
organization important decisions. In fact, a firm is managed by its members of the board of directors, then leadership and guidance transfers from board of directors to General Manager and from General Manager to senior managers. The board of directors are also responsible to manage, supervise, control, and organize routines of the firm on behalf of shareholders. Therefore, executive directors of companies are in charge of routine operations and business process in the firm. Also, board of directors is the ultimate responsible person for operations and financial health of the firm. The main responsibility of board of directors include establishment of efficient governance on the firm's affairs to maintain interests of the shareholders and various beneficiaries including customers, staff, investors and local societies, to prepare an independent supervision on the executive directors' function, and to challenge the strategy and commercial decisions of the executive directors (Mazrae lie, Agha Beiygi, \& Javanshiri, 2016).

There are various definitions of corporate governance such as definitions related to the companies and their shareholders or responsiveness of the companies against numerous groups of shareholders, individuals or stakeholders. Related literature indicates that there is no agreed definition about the corporate governance (Hassas Yeganeh \& Baghoumiyan, 2006)

Corporate governance includes structure, process and rule by which the organization divides power and control amongst the participants. The firm investors want to make sure that their capital in the firm (financial capital, Human Capital and social capital) will lead to return increase. Corporate governance is comprised of all cultural and legal sets and organizational processes which can perform the works of the firm provided to the public. It also refers to those who control the establishment, determine the method of control and procedure of risk allocation and the return emanated from the firm activities (Davis, 2005)

The companies' board of directors must be completely familiar with their companies' specific risk status in determination of the corporate governance in the current fluctuating atmosphere. They must be efficient to the extent that they comfortably question the senior management and prepare complete reports from the sessions of common chairman to the group of board of directors (Heffes, 2009).

\section{Strategic role of Board of Directors and the General Manager}

Judge and Robbins (2007) stated that in organizational aspect, board of directors can be regarded as a group that act to achieve organization objectives. They noted that if the board of directors is placed at an organizational level higher than executive director and other directors, the board of directors can have strategic role on strategic decision makings. Strategic decisions are not daily decisions, but include invariable decisions which are made by the General Managers of the companies and have essential role in the companies' health (Bathula, 2008). Existence of competent board of directors in a firm is accounted as an organizational reserve (Ljungquist, 2007) and competitive advantage for the companies and achievement of a high function (Barney, 1991; Hunt, 2000). Therefore, characteristics of board of directors, General Manager, and their formation have significant effect on strategic decision makings (Bathula, 2008). 


\section{Board of Directors and General Manager Role in the Corporate Governance Determination}

The board of directors is expected to be a focal point of corporate governance in the firm interior and formation and experiment of the firm strategy. This requires spending plenty of time and some believe that a committee of board of directors must be formed and named strategy committee to perform this task. This committee must have a lot of knowledge in the field of the firm commercial activity and sufficient perception of the firm's basic objectives, the strategy to achieve these objectives, the impending difficulties, organization culture and the firm organizing procedure to achieve the determined objectives. Furthermore, this committee must have sufficient and specified information about the strategy and strategic management (Naidoo, 2011).

In the recent decades, pressure on the board of directors for playing more active role in the organization has increased. This is associated with the board of directors' responsiveness in making strategic decisions in the firm. For example, the inborn investors have put the board of directors under pressure for challenging the firm's strategic leadership and following to that interference in the field of governance decision making. Regulations and provisions, in born investors and the firm control market are the most important leverage of pressure on the board of directors for edition of the firm strategy (HassasYeganeh \& Tajik, 2008).

\section{Board of Directors' Characteristics Components}

Board of directors size. The size of board of directors is meant the number of its members. Some of the researchers believe that smaller board of directors in addition to facing less collective difficulty, they cause efficiency increase in decision makings (Yermack, 1996). Some statistical evidence has indicated that the firm function is in contrast with the number of board of directors' members (Wang, Lu, \& Lin, 2012). On the other hand, increasing number of members can prepare utilization of more thought and expertise of more individuals and cause more efficiency of the firm. In this respect, some research expressed the existence of significant and positive relationship between the size of board of directors and the firm function. Some research did not find any significant relationship between the size of Board Director and the firm function (Nikbakht, Seyedi, \& Alhoseheni, 2010).

Non-executive members to the board of directors. It is predicated to those members of the board of directors who do not possess executive responsibility in the firm and have no dependency to the firm as well (Sheri \& Marfou, 2007) and only attend to provision of solution and supervision on the general manager.

Board of directors' independence. It is called the ratio of independence of the board of directors from the general quantity. One of the most important and major firm ruling system factors includes the independence of the board of directors. Responsibility of board of directors consists of independent supervision on the executive director's function and directors' commitment to the responsiveness against shareholders and stakeholders. There is a public belief that when the board of directors possess more independence, exert more effective supervision on executive directors (Solomon, 2007).

Formation and structure of the board of directors. Formation of the board of directors as the ratio of the non-executive board of directors is regarded as the total number of board of 
directors. The more formation of board of directors consists of more independent members, difficulties of the representative decrease (Hermalin \& Weisbach, 1991).

Sessions of the board of directors. Sessions of the board of directors is a place where executive directors and members to the board of directors pose and share their information in terms of the firm function, policies and its plans. Several sessions contribute to establishment of better communication between directors and members to the board of directors. Holding sessions more than enough in addition to their costs (such as time management, transportation charges and wage for attendance in the board of directors' sessions), deviates managers of the firm from their daily and operational responsibilities.

Financial knowledge of board of directors. The supervision on management and participation in decision making requires various skills such as accounting, banking and law so that it can be effective in the firm promotion. The substructure hypothesis of this subject indicates that members with no experience in accounting or financial knowledge have lower capability in discovering the existing problems in financial reporting. Existence of an experienced financial element can make other members sensitive and alert as well.

Distinction of the role of chairman to the board of directors from that of the general manager. If the general manger is a chairman to the board of directors, this refers to as the General Manager Hybrid task. In many of the firm sovereign rules, it has been recommended that a balance should be amongst the members to the board of directors so that no one can control unconditionally the process of decision making in the firm. In addition, the division of responsibilities at the high level in the firm must be specified clearly so that powers balance and authorities limits of board of directors is sufficiently confided (HassasYeganeh \& Baghoumiyan, 2006). Failure to distinct the role of a chairman to the board of directors from that of the general manager makes a single person to be in charge of executive and supervising tasks. In such cases, the chairman to the board of directors (who is the General Manager as well) possesses a lot of powers which leads to spoiling the rights of shareholders.

General Manager Change (occupying duration of the General Manager). Board of directors must elect at least one understrapper as the firm's General Management and determine his authority limits, occupying duration, and his wage in case that the general manager is a member to the board of directors and his management period will not be more than his membership duration in the board of directors. General manager of the firm simultaneously cannot be Chairman to the Board of Directors at the same firm unless approved by three fourth of the present votes in the general assembly. At any moment, board of directors can act on the general manager deposition.

The number of non-executive members to board of directors. Members to board of directors are either executive or non-executive. The executive members in addition to the responsibilities of membership have a physical presence (the same as occupying the position of executive management position in the firm), but the non-executive member has no physical attendance in the firm and only participates in decision makings. As for these individuals according to the article 134 trade law amendment, bill merely must be proportional to the extent of board of directors' sessions in which they participate, wages to be paid. This sum will be determined fixed by the general assembly equally for all non-executive Members and paid by means of check. 
Board of directors' ownership percentage. The formation of board of directors is viewed as the ratio of non-executive members to board of directors to the total number of members to the board of directors.

Using accounting expert in the board of directors. Possessing an accounting expertise by the members of the board of directors is one of the characteristics of the firm's board of directors. The directors must have skill and specific characteristics especially in the field of financial affairs. They must be expert, experienced, and skilled so that they can perform their responsibilities properly (Alkdai \& Hanefah, 2012). The executive and non-executive members of the board of directors possessing financial expertise with more probability will be one of the auditing committee members. Therefore, the auditing committee independence is a key role in the quality of financial reporting. The independence of the board of directors can be effective because they are free from the management influence and in this case the chances of management creative accounting decrease (Klein, 2002).

Chairman to the Board of Directors being non-executive. Presence of non-executive directors in the firm's board of directors is the basis of a modern firm sovereignty. This shows that the executive directors and executive become controlled and supervised effectively (Fama, 1980; Fama \& French, 1993); thus, this will solve the representation issue.

In the following matrix, the board of directors' characteristics components which have been used in the research can be seen. 
Table1

Matrix, Board of Directors' Characteristics

\begin{tabular}{|c|c|c|c|c|c|c|c|c|c|c|c|c|c|c|c|c|c|c|c|}
\hline $\begin{array}{l}\text { Board of directors' } \\
\text { characteristics } \\
\text { components }\end{array}$ & 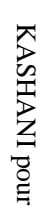 & 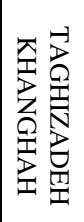 & 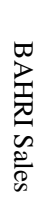 & 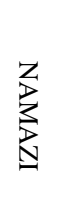 & $\begin{array}{l}\text { 㐒 } \\
\text { 导 }\end{array}$ & 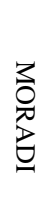 & 胥 & 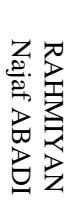 & 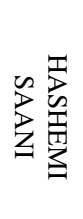 & 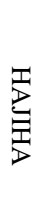 & 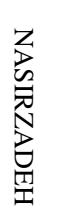 & 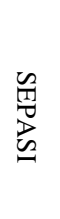 & 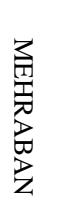 & 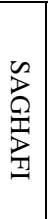 & 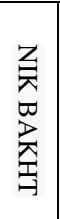 & 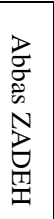 & 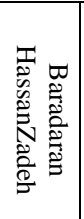 & 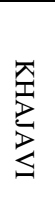 & 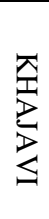 \\
\hline $\begin{array}{l}\text { Non-executive } \\
\text { Members to the } \\
\text { Board of Directors }\end{array}$ & $\checkmark$ & & & $\checkmark$ & $\checkmark$ & $\checkmark$ & & & & $\checkmark$ & & & & $\checkmark$ & & & $\checkmark$ & & $\checkmark$ \\
\hline $\begin{array}{l}\text { Board of directors' } \\
\text { ownership } \\
\text { percentage }\end{array}$ & & & & & $\checkmark$ & & & & $\checkmark$ & & & & $\checkmark$ & & & & & & $\checkmark$ \\
\hline $\begin{array}{l}\text { Board of Directors } \\
\text { Size }\end{array}$ & $\checkmark$ & $\checkmark$ & $\checkmark$ & & $\checkmark$ & $\checkmark$ & $\checkmark$ & $\checkmark$ & $\checkmark$ & $\checkmark$ & $\checkmark$ & & $\checkmark$ & & & $\checkmark$ & $\checkmark$ & $\checkmark$ & $\checkmark$ \\
\hline $\begin{array}{l}\text { Board of Directors } \\
\text { Independence }\end{array}$ & & $\checkmark$ & & & & & $\checkmark$ & & $\checkmark$ & & & & & & & & & $\checkmark$ & \\
\hline $\begin{array}{l}\text { Financial } \\
\text { knowledge of board } \\
\text { of directors }\end{array}$ & & & $\checkmark$ & $\checkmark$ & & & & & & & & & $\checkmark$ & & $\checkmark$ & $\checkmark$ & $\checkmark$ & & \\
\hline $\begin{array}{l}\text { Distinction of the } \\
\text { role of Chairman to } \\
\text { the Board of } \\
\text { Directors from that } \\
\text { of the General } \\
\text { Manager }\end{array}$ & & & & & & & & & & $\checkmark$ & $\checkmark$ & & $\checkmark$ & $\checkmark$ & $\checkmark$ & $\checkmark$ & $\checkmark$ & & \\
\hline $\begin{array}{l}\text { Formation and } \\
\text { structure of the } \\
\text { board of directors }\end{array}$ & & & & & & & & & & & $\checkmark$ & $\checkmark$ & & & $\checkmark$ & & & & \\
\hline $\begin{array}{l}\text { Sessions of the } \\
\text { board of directors }\end{array}$ & & & $\checkmark$ & & & $\checkmark$ & $\checkmark$ & & & & & & & & $\checkmark$ & & & & \\
\hline $\begin{array}{l}\text { Using accounting } \\
\text { expert in the board } \\
\text { of directors }\end{array}$ & & & $\checkmark$ & & & $\checkmark$ & $\checkmark$ & & & & & & & $\checkmark$ & & & & & \\
\hline $\begin{array}{l}\text { occupying duration } \\
\text { of the General } \\
\text { Manager }\end{array}$ & & & & & & & & & & & & & $\checkmark$ & $\checkmark$ & & & & & \\
\hline $\begin{array}{l}\text { Chairman to the } \\
\text { Board of Directors } \\
\text { being non-executive }\end{array}$ & & & & & & & & & & & & & $\checkmark$ & & & & & & \\
\hline $\begin{array}{l}\text { The number of non- } \\
\text { executive members } \\
\text { to board of directors }\end{array}$ & & & & $\checkmark$ & & $\checkmark$ & & & & & & & & & & & & & \\
\hline
\end{tabular}

As shown in Table 2, most of the research have referred to the characteristics of board of directors as the number of members to board of directors, the hybrid responsibility of the General Manager, the ratio of non-executive members, financial knowledge, and the independence of the board of directors.

Table2

Percentage of Research Using Board of Directors' Characteristics Components

\begin{tabular}{|c|c|c|c|c|c|c|c|c|c|c|c|c|}
\hline $\begin{array}{l}\text { Board of } \\
\text { directors' } \\
\text { characteristics } \\
\text { components }\end{array}$ & 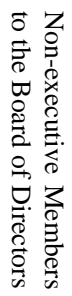 & 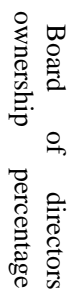 & 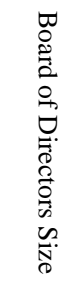 & 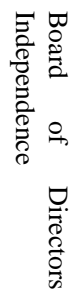 & 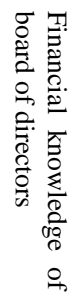 & 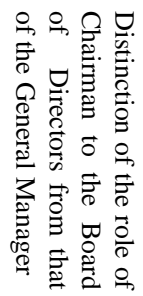 & 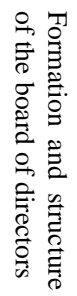 & 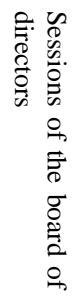 & 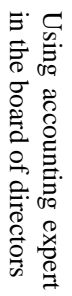 & 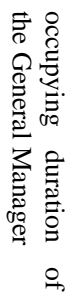 & 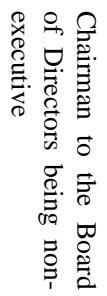 & 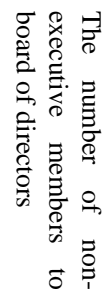 \\
\hline & $42 \%$ & $16 \%$ & $84 \%$ & $21 \%$ & $31 \%$ & $37 \%$ & $31 \%$ & $21 \%$ & $21 \%$ & $10 \%$ & $5 \%$ & $10 \%$ \\
\hline
\end{tabular}


In the studies whose independent variable is the characteristics of the board of directors, the variable depending on them is related to the field of financial, firm value, asset return and equity return with a maximum of iteration.

\section{Personality of General Manager and Board of Directors in Financial and Accounting}

Table3

Dependent Variables in Research whose Independent Variable Has the Characteristics of the Board of Directors

\begin{tabular}{|c|c|c|c|c|c|c|c|c|c|c|c|c|c|c|c|c|c|c|c|c|}
\hline & 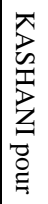 & 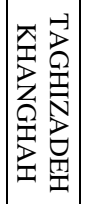 & 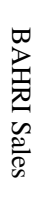 & 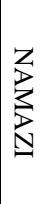 & 超 & $\begin{array}{l}3 \\
0 \\
0 \\
0 \\
0\end{array}$ & 总 & 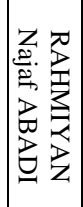 & 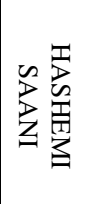 & $\underset{⿱ 乛}{\stackrel{P}{D}}$ & 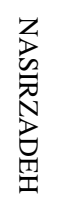 & $\begin{array}{l}\text { 思 } \\
\text { D } \\
\text { 足 }\end{array}$ & 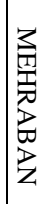 & 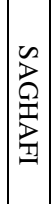 & 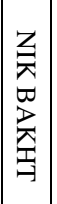 & 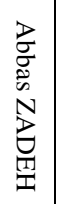 & 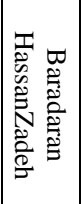 & 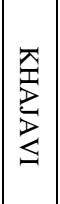 & 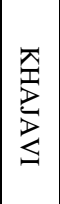 & 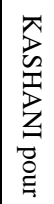 \\
\hline $\begin{array}{l}\text { Ratio of market value to book } \\
\text { value }\end{array}$ & & & & & & & & & & & & & & & & & & & & $\checkmark$ \\
\hline $\begin{array}{l}\text { bankruptcy anticipation models } \\
\text { of ALTMAN and AHLSEN }\end{array}$ & & & & & & & & & & & & & & & & & & & $\checkmark$ & \\
\hline firm value & & & & & & & & & & & & $\checkmark$ & & & & & & $\checkmark$ & & \\
\hline Issue an acceptable report & & & & & & & & & & & & & & & & & $\checkmark$ & & & \\
\hline Income growth & & & & & & & & & & & & & & & & $\checkmark$ & & & & \\
\hline Operating Income growth & & & & & & & & & & & & & & & & & & & & \\
\hline Net profit growth & & & & & & & & & & & & & & & & $\checkmark$ & & & & \\
\hline asset return & & & & & $\checkmark$ & & & $\checkmark$ & & & & & & & & $\checkmark$ & & & & \\
\hline equity return & & & & & & & & $\checkmark$ & & & & & & & & $\checkmark$ & & & & \\
\hline Market value of each share & & & & & & & & & & & & & & & $\checkmark$ & & & & & \\
\hline Accrual quality & & & & & & & & & & & & & & $\checkmark$ & & & & & & \\
\hline Profit sustainability & & & & & & & & & & & & & & $\checkmark$ & & & & & & \\
\hline Smoothing Profit & & & & & & & & & & & & & & $\checkmark$ & & & & & & \\
\hline The relationship of profit value & & & & & & & & & & & & & & $\checkmark$ & & & & & & \\
\hline Conservatism & & & & & & & & & & & & & $\checkmark$ & $\checkmark$ & & & & & & \\
\hline financial risk & & & & & & & & & & & $\checkmark$ & & & & & & & & & \\
\hline $\begin{array}{l}\text { the structure of the firm debt } \\
\text { deadline }\end{array}$ & & & & & & & & & & $\checkmark$ & & & & & & & & & & \\
\hline agency costs & & & & & & & & & $\checkmark$ & & & & & & & & & & & \\
\hline charges of banking borrowing & & & & & & & $\checkmark$ & & & & & & & & & & & & & \\
\hline real earnings management & & & & & & $\checkmark$ & & & & & & & & & & & & & & \\
\hline timing of financial reporting & & & & $\checkmark$ & & & & & & & & & & & & & & & & \\
\hline selection of auditor & & & $\checkmark$ & & & & & & & & & & & & & & & & & \\
\hline tax strategy & & & & & & & & & & & & & & & $\checkmark$ & & & & & \\
\hline company strategy & & $\checkmark$ & & & & & & & & & & & & & & & & & & \\
\hline voluntary disclosure & 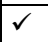 & & & & & & & & & & & & & & & & & & & \\
\hline
\end{tabular}

\section{Discussion and Conslusion}

The role of management and leadership in organizations is an outstanding, key and irreplaceable role. No organization can be found that have experienced stable status but does not benefit from the existence of a wise director and competent leader. The importance of role of directors in organizations is to the extent that some of experts have reckoned the existence of a competent manager for success of an organization as sufficient, since they believe that presence of this key factor will lead to creation, attraction, reserving and improvement of other required factors for success of the organization. All of the directors are directors since they don't act in one way like other people of the society they have their own personal differences, aptitudes, motivations and tendencies. These differences might be minor superficially, but when they pass cognitive mediator processes, can result in very huge differences and 
behavioral results. Such differences are majorly originated from differences of the personality of each of people (NaderianJahromi \& Amirhosseini, 2007).

Since directors benefit from more authority and decision making in comparison with the regular people and other staff, their personality can be effective in their decisions and their methods. In other words, directors possess personal philosophy which affects their view to different issues and staff around them and their activities. The style and managerial philosophy of each director is affected by the personality and culture factor. Psychology and accounting are two scientific domains which in the recent several decades have passed each other's borders and in several fields overlapped each other. One of these cases happen at the time of financial decision makings in which personal judgments and emotions of the accountants and managers especially the general manager influence their decisions and somehow what happens in the minor behavioral financial literature we witness the same phenomenon in here. In fact, the spiritual status, personal, and professional characteristics have an especial effect on the type of decision and its results are possibly at the same direction or different from the result of intellectual decision.

This research identified the characteristics of board of directors scales which each one had advantages and disadvantages. Application of a specific technique depends on the objective and substrate of the research. If the objective of research is the explanation of the board of directors' characteristics or board of directors' characteristics differences in a specific substrate, selection of the scale of board of directors' characteristics can be different with that of a scale of board of directors' characteristics in a study seeking or proving the results of board of directors' characteristics. Where characteristics of the board of directors is only a controlled variable, a virtual simple variable might be sufficient. In the emerging markets, there is no index of board of directors' characteristics from the prior studies or in professional organizations. Thus, a researcher must increase his scale of the board of directors' characteristics depending upon his research objectives. Furthermore, an access to data plays the main role in acceptance of a specific technique of board of directors' characteristics measurement. For example, many studies related to the board of directors' characteristics apply the term of non-executive members and the general managers' hybrid responsibility since these scores exist for many companies. Future researchers may regard more than one estimation application for board of directors' characteristics.

In this study we examined the board of directors' characteristics in two domains of components related to board of directors' characteristics and its effect on the other variables. We examined the components that are utilized for board of directors' characteristics in most studies. The existing gap of the discussion in such studies is the personality of the general manager and members to the board of directors. Regarding the effect of individuals' personality in decision making it is convenient that comprehensive research to be conducted in this field and in addition to the discussed components about the board of directors' characteristics, the personality component also to be added to them.

\section{References}


Abbas Zadeh, M. R., \& ManzarZadeh, H. (2011). Examining a possible issuing of accepted reports of the independcent audits by considering board of directors' characteristics in the accepted companies at Tehran Stock Exchange. Journal of accounting and auditing considerations, 18, 95-112.

Alkdai, H. K. H., \& Hanefah, M. M. (2012). Audit committee characteristics and earnings management in Malaysian Shariahcompliant companies. Business and Management Review, 2(2), 52-61.

Arabi, M., \& Hasanpour, S. (2015). The relationship between board characteristics and timing of financial reporting. Financial accounting knowledge, 3, 107-132.

Bahri Sales., J., Behnamoun, Y., \& HossenZadeh, G. (2013). Board of directors’ characteristics and connectivity of accounting information in the accepted companies at Tehran Stock Exchange. Journal of Accounting Knowledge and Management Auditing, 6, 51-64.

Barney, J. (1991). Firm resources and sustained competitive advantage. Journal of management, 17(1), 99-120.

Bathula, H. (2008). Board characteristics and firm performance: Evidence from New Zealand (Doctoral dissertation). Auckland University of Technology.

Davis, G. F. (2005). New directions in corporate governance. Annual Review of Sociology, 31, 143-162.

Fama, E. F. (1980). Agency problems and the theory of the firm. Journal of political economy, 88(2), 288-307.

Fama, E. F., \& French, K. R. (1993). Common risk factors in the returns on stocks and bonds. Journal of financial economics, 33(1), 3-56.

Hajiha, Z., \& Akhlaghi, H. (2013). Hajiha, Z., Akhlaghi, H. (2013). The effect of board characteristics on debt maturity structure of companies listed in Tehran Stock Exchange. Journal of Management Accounting, 6(17), 59-74

HashemiSaani, M. (2017). Board of directors' characteristics, assets return and capital return: Case study in the banking industry (Unpublished master's thesis). Azad University, Sabzevar.

Baradaran Hassan Zadeh, R., Azimi, M. (2013). Considering the effect of capital structure and board of directors' characteristics on the value of the firm amongst 50 superior companies of Tehran Stock Exchange. Paper presented at the Eleventh National Convention of IRAN Accounting, Ferdoosi University, Mashahd.

HassasYeganeh, Y., \& Tajik, k. (2008). Firm sovereignty of board of directors and interaction with the environment. Accountant Journal, 205, 62-68.

HassasYeganeh, Y., \& Baghoumiyan, R. (2006). The role of board of directors in the firm sovereignty. Accountant journal, 173, 26-30.

Heffes, E. M. (2009). Directors' roles in assessing strategy. Financial Executive, 25(2), 10-11.

Hermalin, B. E., \& Weisbach, M. S. (1991). The effects of board composition and direct incentives on firm performance. Financial management, 101-112.

Hunt, S. D. (2000). A general theory of competition: too eclectic or not eclectic enough? Too incremental or not incremental enough? Too neoclassical or not neoclassical enough? Journal of Macro marketing, 20(1), 77-81.

Judge, T. A., Langton, N., \& Robbins, S. P. (2007). Organizational behaviour: Concepts, controversies and applications. Canada: Pearson.

Kashani pour, M., Karimi, H., \& Karimi, V. (2014). The relation of ownership and board structure with voluntary disclosure. Journal of Empirical Research in Accounting, 2, 167-186.

Khajavi, A \&Ghorbani, A; Nikkaar, J; Bazraaei, Y (2014). considering board of directors' characteristics on the firm function at different levels of market competition, accounting researches and auditing, sixth year, No. 24.

Khajavi, S., \& Farajpourbandi, F (2012). the effect of board of directors' characteristics on bankruptcy anticipation models of Altman and Ahlsen. Applied Researches in Financial Reporting, 1, 107-132.

Klein, A. (2002). Audit committee, board of director characteristics, and earnings management. Journal of accounting and economics, 33(3), 375-400.

Ljungquist, U. (2007). Core competency beyond identification: Presentation of a model. Management Decision, 45(3), 393402.

Mazrae lie, Y., Agha Beiygi, M, \&Javanshirinezhad, Z, (2016). Considering the effect of common board of directors' member on the level of revealing and profit quality of the companies accepted in Tehran Stock Exchange. Journal of Economics and Tax, 2(1), 57-78.

Mehraban, M., Zolfi, H., \& Malihi, S. A. (2015). Considering board of directors' characteristics on conservative act of accounting in the companies accepted at Tehran Stock Exchange. Journal of Audition Knowledge, 58, 171-188. 
Moradi, M., Habibzadehbaygi, J., Najariyan, M., \& Taghavimoghaddam, A. (2012). Application of fuzzy regression in expression of the relationship between board of directors' characteristics and function of Tehran Stock Exchange accepted companies. Journal of Accounting Advancements, 2, 119-150.

NaderianJahromi, M., \& Amirhosseini, S. E. (2007). Study of the relationship between personality traits and demographic of athletic managers with their job skills. Journal of Olympics, 15(4), 105-114

Naidoo, M. (2011). The board of directors: Governance is the bottom-line. Accountancy, 34-35.

Namazi, M., \& Saeidi, M. (2014). the relationship between board of directors' characteristics and selection of auditor. The Financial Accounting and Auditing Researches, 22, 1-28,

Nasirzadeh, F., Salehi, M., \& Beygi, B. (2015). Board of directors structural and processing characteristics and financial risk: Change in the cash, change in the financial crisis. Journal of Accounting Knowledge, 22, 81-105.

Nikbakht, M., Seyedi, S. A., \& Alhosseini Roozbeh, H. (2010). Considering the effect of board of directors' characteristics on the firm function. Journal of Accounting Advancements, 2, 251-270,

Rahimi, R (2014). The relationship between board of directors' characteristics and the real earnings management (Unpublished master's thesis). KAR non-profit non-governmental higher education Institute: Tehran.

Rahmiyan Najafabadi, S. (2016). Effects of board of directors' characteristics on the charges of banking borrowing in Tehran Stock Exchange companies using the method of Guantal Regression (Unpublished master's thesis). Najaf Abad: Azad University.

Saghafi, A., \& Safarzadeh, M. (2011). Profit quality and board of directors' characteristics: Empirical analysis. Journal of Accounting Knowledge, 44, 73-94.

Sepasi, S., \& Abdoli, L. (2014). Effects of women presence in the board of directors on the firm value and financial function. The Financial Accounting and Auditing Researches, 29, 39-58.

Sheri, S., \& Marfou, M. (2007). The relationship of the non-executive members in the formation of board of directors and institutional investors with anticipation of the companies' profit. Empirical Studies of Financial Accounting, 5(17), 63-104.

Solomon, J. (2007). Corporate governance and accountability. United States: John Wiley \& Sons.

Taghizadeh khanghah, V., \& Zeynali, M. (2016). Effect of board of directors' characteristics and entrenchment of management on firm diversification. Financial Management Strategy, 16, 135-157.

Wang, W. K., Lu, W. M., \& Lin, Y. L. (2012). Does corporate governance play an important role in BHC performance? Evidence from the US. Economic Modelling, 29(3), 751-760.

Yermack, D. (1996). Higher market valuation of companies with a small board of directors. Journal of financial economics, 40(2), 185-211. 